\title{
BIOACTIVE COMPOUNDS IN TOMATOES AT DIFFERENT STAGES OF MATURITY
}

\author{
Māra Dūma ${ }^{1, \#}$, Ina Alsiṇa ${ }^{2}$, Laila Dubova ${ }^{2}$, and leva Erdberga ${ }^{2}$ \\ ${ }^{1}$ Faculty of Food Technology, Latvia University of Life Sciences and Technologies, 22 Rīga Str., Jelgava, LV-3001, LATVIA \\ ${ }^{2}$ Faculty of Agriculture, Latvia University of Life Sciences and Technologies, 2 Liela Str., Jelgava, LV-3001, LATVIA \\ \# Corresponding author: mara.duma@llu.Iv
}

Contributed by Ina Alsiṇa

\begin{abstract}
Tomato is known as a vegetable with several health benefits due to its high level of bioactive compounds, especially lycopene, phenolics, and vitamin C. The effect of tomato variety and stage of maturity on the bioactive compounds concentration was studied. Ten tomato varieties were grown and collected from a greenhouse at two different stages of ripening. The obtained results showed that there were significant differences in the mean values between analysed parameters according to the stage of ripening and variety. The highest concentration of vitamin $C$ was determined for variety Sakura F1 at maturity stage, and the lowest for variety Sunstreem F1 for unripe fruits. The concentration of phenols and flavonoids increased during tomato ripening and the highest rate was observed for variety Naget F1 (from $7.86 \mathrm{mg} \cdot 100 \mathrm{~g}^{-1}$ to $14.34 \mathrm{mg} \cdot 100 \mathrm{~g}^{-1}$ (phenols) and flavonoids from $6.09 \mathrm{mg} \cdot 100 \mathrm{~g}^{-9}$ to $10.03 \mathrm{mg} \cdot 100 \mathrm{~g}^{-1}$. The concentration of lycopene in the unripe stage was low (mostly about $1 \mathrm{mg} \cdot 100 \mathrm{~g}^{-1}$ ) and the most quantitative changes and the highest concentration of lycopene in full maturity stage was determined for variety SV0946TS $\left(27.11 \mathrm{mg} \cdot 100 \mathrm{~g}^{-1}\right)$ and variety NectarF1 (16.81 mg.100 $\left.\mathrm{g}^{-1}\right)$.
\end{abstract}

Key words: Solanum lycopersicum L., phytonutrients, ripening.

\section{INTRODUCTION}

Tomatoes (Solanum lycopersicum L.) are a very popular vegetable with good nutritive value, well-known worldwide and are recognised as a health promoting food (Vinha et al., 2014a). Tomato fruits are rich in vitamins (A, C, K, B1, B2, B3, PP), a good source of minerals (potassium, sodium, magnesium, copper, calcium, iron, sulphur, phosphorous), and contain organic acids, sugars, dietary fibre, many phenolic compounds and carotenoids - lycopene and $\beta$ carotene (Choi et al., 2010; Bhowmik et al., 2012).

The health benefits of tomatoes have been known since ancient times. Tomatoes are one of the most important sources of biological active and health promoting compounds, mainly lycopene and other carotenoids, as well as flavonoids and tocopherols, which are reported as protective compounds against cancer, diabetes, and cardiovascular diseases (Shi et al., 2008; Burda, 2014). It has been suggested that consuming tomatoes may reduce the risk of several chronic diseases such as cancer, cardiovascular and cerebrovascular diseases, diabetes and hypertension (Blum et al. 2005; Das et al, 2005).

The content of biological active compounds and their antioxidant activity varies significantly depending on ripen- ing, variety and environmental conditions (Brandt et al., 2006).

Tomato fruit colour is one of the important indices of tomato maturity stage and quality; it changes during ripening. The green colour of unripe tomato fruits is due to the presence of chlorophyll. During maturation the degradation of this pigment takes place and synthesis of yellow pigments such as $\beta$-carotene and xanthophylls is induced. The colour of tomato fruits varieties differ from yellow to orange-red depending on the lycopene: $\beta$-carotene ratio (De Sousa et al., 2014).

Synthesis of pigments in tomatoes is related to the ripening processes and red colour of tomatoes results from the accumulation of lycopene (Helyes and Pék, 2006). Therefore, the content of lycopene has been suggested as a good indicator of the level of ripening. Lycopene is considered to be the predominant carotenoid of tomato fruit (80-90\%), followed by $\beta$-carotene (5-10 \%) (Lenucci et al., 2006). Lycopene appears to act as an antioxidant when consumed in food, neutralising free radicals that can damage cells in the body. Cancers such as prostate cancer, cervical cancer, colon cancer, rectal cancer have all been proven to be staved off by high levels of lycopene. Lycopene has been observed to prevent the continued growth cancer cell cultures (Bhowmik et al., 2012). 
The aim of this study was to describe differences in concentration of biologically active compounds in tomato depending on variety and stage of maturity.

\section{MATERIALS AND METHODS}

The study was carried out at the Latvia University of Agriculture, Institute of Soil and Plant Sciences.

Ten varieties of tomato plants were grown in a greenhouse from 1 May till 21 August 2015.

Tomato sampling. For analysis, a cluster of tomato with fruits at different stages of ripening was removed. The samples selected for experiments were classified into two stages of ripening: green - fruit surface is completely green; and red - more than $80 \%$ of the surface shows red (orange) colour. Five tomatoes at each stage of maturation were randomly selected for analysis, weighed, hand-rinsed with pure water, shaken to remove water, blotted with a paper towel, then mixed and homogenised. Samples from the obtained puree were taken in triplicate to measure concentration of vitamin $\mathrm{C}$ and lycopene as well as concentration of total phenols and flavonoids.

Chemicals and spectral measurements. All the reagents used were analytical grade and obtained from Sigma Aldrich, Germany. An UV spectrophotometer UV-1800 (Shimadzu Corporation, Japan) was used for the absorbance measurements.

Analytical methods. Determination of vitamin C concentration. The concentration of vitamin $\mathrm{C}$ was determined titrimetrically using 2.6-dichlorphenolindophenol. For determination $2 \pm 0.001 \mathrm{~g}$ of tomato puree was quantitatively transferred in $100 \mathrm{ml}$ tubes, $50 \mathrm{ml} 1 \% \mathrm{HCl}$ and $5 \% \mathrm{HPO}_{3}$ mixture $(1: 1 \mathrm{v} / \mathrm{v})$ was added and mixed thoroughly. After 30 minutes the solution was filtered through a filter paper No. $89^{\text {th }}$. For determination, $10 \mathrm{ml}\left(\mathrm{V}_{\mathrm{a}}\right)$ filtrate was titrated with 0.0005 molar solution of 2.6-dichlorphenolindophenol $\left(\mathrm{V}_{\text {titr }}\right)$.

The concentration of vitamin $\mathrm{C}$ was calculating according to the equation (1):

Vitamin C $\left(\mathrm{mg} \cdot 100 \mathrm{~g}^{-1}\right)=\frac{V_{\text {titr }} \cdot 0.044 \cdot V_{\text {total }} \cdot 100}{V_{a} \cdot \text { weight }}$

Determination of lycopene concentration. For extraction a representative portion of tomato sample $(0.5 \pm 0.0001 \mathrm{~g})$ was accurately weighed in a glass test tube. Then $10 \mathrm{ml}$ solvent (acetone/hexane $2: 3, \mathrm{v} / \mathrm{v}$ ) was added to it and the test tubes were held for $15 \mathrm{~min}$ with occasional shaking at room temperature and finally centrifuged for $10 \mathrm{~min}$ at $5000 \mathrm{rpm}$. The absorbance of supernatants were analysed spectrophotometrically by absorption measurements at 350 to $700 \mathrm{~nm}$ and calculated in accordance with Nagata and Yamashita (1992).

Determination of total flavonoid concentration. The total flavonoid concentration was measured by a colorimetric method (Kim et al., 2003) with a minor modification. For extraction $1.0 \pm 0.001 \mathrm{~g}$ of finely ground tomatoe samples was weighed into volumetric flasks and $10 \mathrm{ml}$ ethanol was added, then shaken at $20{ }^{\circ} \mathrm{C}$ for $60 \mathrm{~min}$ in the dark and centrifuged for $10 \mathrm{~min}$ at $5000 \mathrm{rpm}$.

To $0.5 \mathrm{~mL}$ of extract $2 \mathrm{ml}$ of double distilled $\mathrm{H}_{2} \mathrm{O}$ was added, and mixed with $0.15 \mathrm{ml} 5 \%$ sodium nitrite $\left(\mathrm{NaNO}_{2}\right)$ $\left(50 \mathrm{~g} \cdot \mathrm{l}^{-1}\right)$. After $5 \mathrm{~min}, 0.15 \mathrm{ml} 10 \%$ aluminium chloride $\left(\mathrm{AlCl}_{3} \cdot 6 \mathrm{H}_{2} \mathrm{O}\right)$ solution was added. The mixture was allowed to stand for another $5 \mathrm{~min}$, and then $1 \mathrm{ml} 1 \mathrm{M}$ sodium hydroxide $(\mathrm{NaOH})$ was added. The reaction solution was mixed well. After $15 \mathrm{~min}$ of incubation at room temperature, the absorbance was measured at $415 \mathrm{~nm}$. Total flavonoid concentration was expressed as catehin equivalents $100 \mathrm{~g}^{-1}$ fresh weight of the tomatoes.

Determination of total phenolic concentration. For extraction of total phenolics $1.0 \pm 0.001 \mathrm{~g}$ of finely ground tomatoes samples was weighed into volumetric flasks, $10 \mathrm{ml}$ of extractant, a mixture of methanol, distilled water and hydrochloric acid $(79: 20: 1 \mathrm{v} / \mathrm{v} / \mathrm{v})$ were added. The vials were shaken at $20{ }^{\circ} \mathrm{C}$ for $60 \mathrm{~min}$ in the dark, then centrifuged for $10 \mathrm{~min}$ at $5000 \mathrm{rpm}$. The total phenolic concentration of the tomatoes samples was determined using the Folin-Ciocalteu (FC) spectrophotometric method (Singleton et al., 1999) with some modifications. To $0.5 \mathrm{ml}$ of extract $2.5 \mathrm{ml}$ Folin-Ciocalteu reagent (diluted 10 times with water) and, after 3 minutes $2 \mathrm{ml}$ sodium carbonate $\mathrm{Na}_{2} \mathrm{CO}_{3}\left(75 \mathrm{~g} \cdot \mathrm{l}^{-1}\right)$ was added. The sample was mixed. After $2 \mathrm{~h}$ of incubation at room temperature, the absorbance was measured at $765 \mathrm{~nm}$. Total phenol concentration was expressed as gallic acid equivalents (GAE) $100 \mathrm{~g}^{-1} \mathrm{FW}$ of tomatoes.

Statistical analysis. Data were expressed as mean of assayed triplicates \pm standard deviation; for mathematical data processing the value of $p \leq 0.05$ was regarded as statistically significant. One-way analysis of variance (ANOVA) was used to determine the significance of differences.

\section{RESULTS}

All tomato samples analysed in this study were classified depending on colour and size. Depending on the colour at the end of ripening there were five yellow or orange varieties (Apresa F1, Beorange F1, Matthew F1, Nugget F1, Organza F1) and five red varieties (Lancelot F1, Nectar F1, Sakura F1, Sunstream F1, SV0946TS). Depending on size of tomatoes fruits we could distinguish four cherry type tomato varieties (Apresa F1, Nectar F1, Nugget F1, Sakura F1) and six plum type or bigger size tomatoes (Sunstream F1, Organza F1, Lancelot F1, Beorange F1, Matthew F1, SV0946TS).

The concentration of total phenols (Table 1) expressed as mg GAE $100 \mathrm{~g}^{-1} \mathrm{FW}$ was very variable and tomato variety and stage of maturity had a significant $(p<0.05)$ effect.

Total phenol concentration was significantly higher $(p<$ $0.05)$ in the red stage $\left(6.77-14.34 \mathrm{mg} \mathrm{GAE} \cdot 100 \mathrm{~g}^{-1}\right)$ com- 
Table 1

THE CONCENTRATION OF TOTAL PHENOLS AND FLAVONOIDS DEPENDING ON STAGE OF MATURITY AND TOMATO VARIETY

\begin{tabular}{|c|c|c|c|}
\hline $\begin{array}{l}\text { Tomato } \\
\text { variety }\end{array}$ & $\begin{array}{c}\text { Stage } \\
\text { of maturity }\end{array}$ & $\begin{array}{l}\text { Total phenols } \\
\text { mg GAE } 100 \mathrm{~g}^{-1}\end{array}$ & $\begin{array}{c}\text { Total flavonoids mg } \\
\text { catechin } 100 \mathrm{~g}^{-1}\end{array}$ \\
\hline \multirow[t]{2}{*}{ Apresa F1 } & green & $6.59 \pm 0.38$ & $4.86 \pm 0.13$ \\
\hline & red & $11.89 \pm 0.34$ & $5.82 \pm 0.17$ \\
\hline \multirow[t]{2}{*}{ Beorange F1 } & green & $4.79 \pm 0.38$ & $2.17 \pm 0.08$ \\
\hline & red & $6.86 \pm 0.46$ & $2.87 \pm 0.07$ \\
\hline \multirow[t]{2}{*}{ Lancelot F1 } & green & $4.99 \pm 0.04$ & $3.65 \pm 0.12$ \\
\hline & red & $6.91 \pm 0.48$ & $5.08 \pm 0.20$ \\
\hline \multirow[t]{2}{*}{ Matthew F1 } & green & $6.58 \pm 0.31$ & $3.94 \pm 0.36$ \\
\hline & red & $8.15 \pm 0.46$ & $4.6 \pm 0.09$ \\
\hline \multirow[t]{2}{*}{ Nectar F1 } & green & $6.42 \pm 0.27$ & $6.42 \pm 0.17$ \\
\hline & red & $10.28 \pm 0.22$ & $8.95 \pm 0.16$ \\
\hline \multirow[t]{2}{*}{ Nugget F1 } & green & $7.86 \pm 0.17$ & $6.09 \pm 0.14$ \\
\hline & red & $14.34 \pm 0.09$ & $10.03 \pm 0.33$ \\
\hline \multirow[t]{2}{*}{ Organza F1 } & green & $4.83 \pm 0.45$ & $3.95 \pm 0.09$ \\
\hline & red & $6.77 \pm 0.47$ & $5.46 \pm 0.06$ \\
\hline \multirow[t]{2}{*}{ Sakura F1 } & green & $8.09 \pm 0.21$ & $6.67 \pm 0.21$ \\
\hline & red & $12.69 \pm 0.29$ & $7.68 \pm 0.14$ \\
\hline \multirow[t]{2}{*}{ Sunstream F1 } & green & $6.13 \pm 0.88$ & $4.38 \pm 0.08$ \\
\hline & red & $11.42 \pm 0.43$ & $5.76 \pm 0.12$ \\
\hline \multirow[t]{2}{*}{ SV0946TS } & green & $6.34 \pm 0.31$ & $5.71 \pm 0.19$ \\
\hline & red & $8.58 \pm 0.32$ & $6.47 \pm 0.24$ \\
\hline
\end{tabular}

pared to that in the green stage (4.79-8.09 mg GAE-100 $\mathrm{g}^{-1}$ ). The highest phenol concentration was observed in Nugget F1 (orange cherry type tomato) at red maturity stage $\left(14.34 \pm 0.09 \mathrm{mg} \mathrm{GAE} \cdot 100 \mathrm{~g}^{-1}\right)$. Among plum type or bigger size tomatoes, the highest increase of phenol concentration during ripening was observed in variety SV0946TS $\left(6.34-8.58 \mathrm{mg} \mathrm{GAE} \cdot 100 \mathrm{~g}^{-1}\right)$.

The data of investigations showed that total flavonoid concentrations (Table 1) expressed as mg catechin $100 \mathrm{~g}^{-1} \mathrm{FW}$ differed significantly $(p 0.05)$ between the variety and stage of maturity. The range in flavonoid concentration was higher at red stage $\left(2.87-10.03 \mathrm{mg}\right.$ catechin $\left.100 \mathrm{~g}^{-1}\right)$ and lower at green stage (2.17-6.67 mg catechin $\left.\cdot 100 \mathrm{~g}^{-1}\right)$. The highest concentration at red maturity stage was in variety Nugget F1 $\left(10.03 \pm 0.33 \mathrm{mg}\right.$ catechin $\left.100 \mathrm{~g}^{-1}\right)$, but at the green stage in Sakura F1 $\left(6.67 \pm 0.21 \mathrm{mg}\right.$ catechin $\left.\cdot 100 \mathrm{~g}^{-1}\right)$. The tomato variety Beorange F1 had the lowest total flavonoids concentration at green $(2.17 \pm 0.08 \mathrm{mg}$ catechin $\left.100 \mathrm{~g}^{-1}\right)$ and red $\left(2.87 \pm 0.07 \mathrm{mg}\right.$ catechin $\left.\cdot 100 \mathrm{~g}^{-1}\right)$ stages of maturity.

The concentration of vitamin $\mathrm{C}$ depended on tomato variety and stage of maturity (Fig. 1). It varied from $4.14 \pm 0.09$ $\mathrm{mg} \cdot 100 \mathrm{~g}^{-1}$ (variety SV0946TS) till $8.07 \pm 0.11 \mathrm{mg} \cdot 100 \mathrm{~g}^{-1}$ (variety Beorange F1) at green stage among plum type tomatoes. Vitamin C concentration differed statistically significantly also at green stage of cherry tomatoes. Average data showed that the lowest concentration was in fruits of Sunstream F1 $\left(1.93 \pm 0.08 \mathrm{mg} \cdot 100 \mathrm{~g}^{-1}\right)$, and the highest in Nectar F1 (11.11 $\left.\pm 0.14 \mathrm{mg} \cdot 100 \mathrm{~g}^{-1}\right)$. During ripening the concentration of vitamin $\mathrm{C}$ increased in all analysed tomato samples and at red stage of maturity the highest concentration was in cherry type tomato variety Sakura F1 (22.82 \pm $\left.0.25 \mathrm{mg} \cdot 100 \mathrm{~g}^{-1}\right)$.

The results of experiments showed that concentration of lycopene significantly $(p<0.05)$ depended on the tomato variety and stage of maturity (Fig. 2). The lowest lycopene concentration was determined in tomato variety Nectar F1 at green stage $\left(0.58 \pm 0.09 \mathrm{mg} \cdot 100 \mathrm{~g} \mathrm{~g}^{-1}\right)$ and tomato variety Beorange F1 at red stage $\left(3.08 \pm 0.18 \mathrm{mg} \cdot 100 \mathrm{~g}^{-1}\right)$; the highest lycopene concentration $\left(27.11 \pm 1.05 \mathrm{mg} \cdot 100 \mathrm{~g} \mathrm{~g}^{-1}\right)$ was obtained in samples of red tomato variety SV0946TS at full ripening stage, which was significantly higher $(p<$ 0.05 ) than in other tomato samples. Our studies showed that the concentration of lycopene significantly increased during ripening. Comparing different size tomatoes, the highest lycopene concentration was found in cherry type tomatoes as in plum type tomatoes excepting variety SV0946TS, which can be explained by the colour of these tomatoes.

\section{DISCUSSION}

One of the main reason why tomato is recommended in the diet by dieticians is the high level of biological active com-

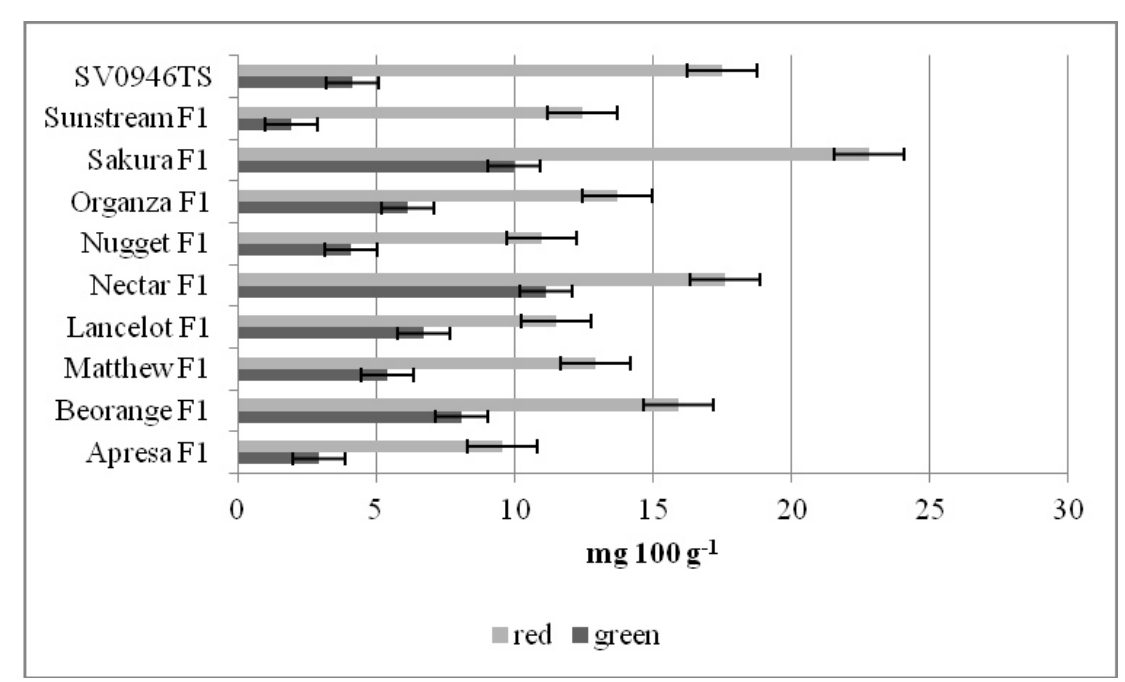

Fig. 1. Concentration of vitamin $\mathrm{C}$ depending on variety and stage of tomato maturity. 


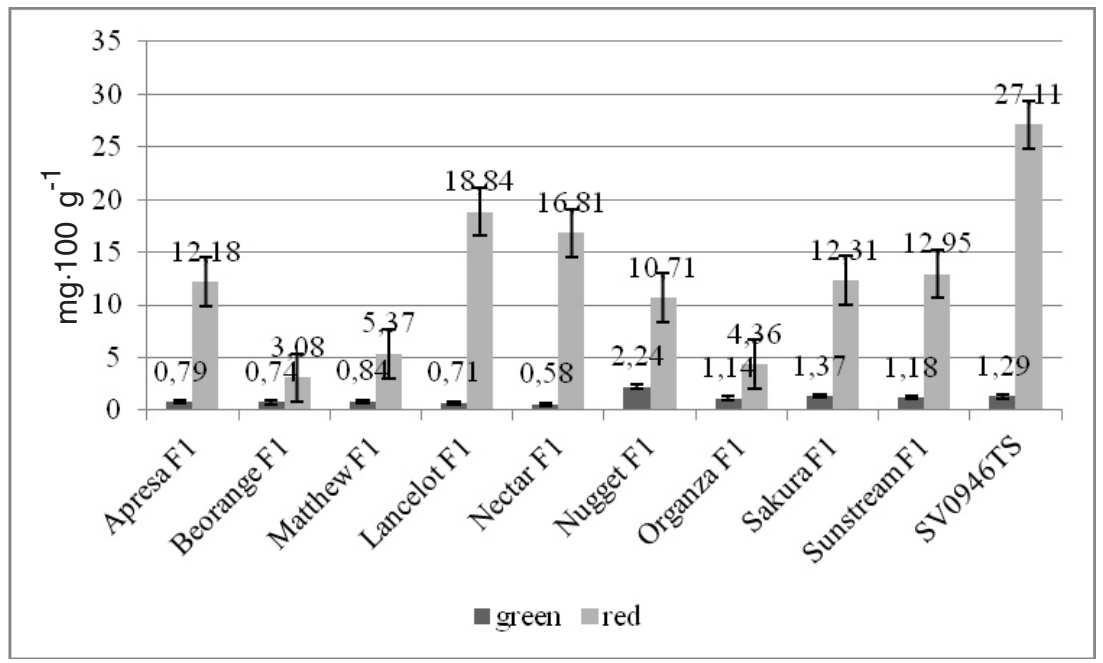

Fig. 2. Concentration of lycopene depending on variety and stage of tomato maturity.

pounds in the fruits - such antioxidants as phenolics, vitamin C and lycopene (Vallverdś-Queralt et al, 2011; Vinha et al., 2014a). These phytonutrients have been associated with many health benefits such as reducing inflammation, and decreasing the amount of cholesterol (Lenucci et al., 2006; Palozza et al., 2010; Ried and Fakler, 2011).

In our study, the total phenolic concentration in cherry type tomatoes was considerably higher than in plum type tomatoes, regardless of the stage of maturity. The concentrations reported here are in line with data of scientific literature (George et al., 2011; Maršic et al., 2011; SánchezRodríguez et al., 2012), which report total phenolic concentration in cherry tomatoes ranging from 5.0 to $15.00 \mathrm{mg} \cdot 100$ $\mathrm{g}^{-1}$. Stewart et al. (2000) explained the higher levels of total phenolic concentration in cherry tomatoes, compared to cultivars with larger fruits, with the higher skin to volume ratio of these varieties, which could raise their phenolic concentration, since these compounds occur within the skin of the fruit.

Other studies have found a higher level of total phenolics in tomato fruits than observed in our trials (Vinha et al., $2014 a$; 2014b). This disagreement could be caused by different agronomic factors such as varieties, weather and growing conditions as well as harvest time.

The changes of total phenol concentration during ripening were similar for cherry and plum type tomatoes - on average this parameter increased by 1.7 times. Some researchers also reported that concentration of total phenolics strongly depends on the ripening stage of tomato fruits, as it has higher concentration in green and intermediate ripening stages, decreasing in full red tomatoes (Choi et al., 2010; García-Valverde et al., 2013).

Flavonoids are commonly classified as "environmental compounds" because they are often produced in direct response to environmental conditions (Sánchez-Rodríguez et al., 2012).

The obtained results showed that concentration of total flavonoids (mg catechin.100 $\mathrm{g}^{-1}$ ) in cherry type tomatoes (from $4.86 \pm 0.13$ to $6.67 \pm 0.21$ at green stage and $5.82 \pm$
0.17 to $10.03 \pm 0.33$ at red stage) was considerably higher than in plum type tomatoes (from $2.17 \pm 0.08$ to $5.71 \pm 0.19$ in green stage and from $2.87 \pm 0.07$ till $6.47 \pm 0.24$ in red stage). The obtained results are in line with the findings of others regarding concentration of total phenols. As a dietary component, flavonoids are thought to have health promoting properties mainly due to their high antioxidant capacity (Pietta, 2000). Therefore, cherry type tomatoes are more "healthier" than plum or bigger size tomato fruits. Our results agree with the results of Sánchez-Rodríguez et al. (2012) who observed that concentration of flavonoids (at red stage) was between 7.89 and $14.22 \mathrm{mg} \cdot 100 \mathrm{~g}^{-1}$ depending on variety and growing conditions. The increase of total flavonoid concentration was similar for cherry and plum type tomatoes - it increased on average by 1.3 times.

Tomato also contains significant levels of the antioxidant vitamin $\mathrm{C}$, which has an essential role against oxidative stress - (Vinha et al., 2014a).

Levels of vitamin $\mathrm{C}$ found in the present study are consistent with some data reported in the literature (Erba et al., 2013), but lower than others (Vinha et al., 2014a; 2014b). The average concentration of vitamin $\mathrm{C}$ in cherry type tomatoes was significantly higher $(p<0.05)$ than in plum type tomatoes, regardless of maturity stage.

It is generally considered that vitamin $\mathrm{C}$ increases with ripening in tomato fruit (Dumas et al., 2003; Gautier et al., 2008), but in the scientific literature also other trends have been found (Del Giudice, 2015). Some authors have observed no clear trend during ripening while others have found that vitamin $\mathrm{C}$ concentration increased slightly only at the last stage of ripening (García-Valverde et al., 2013). Our results showed that content of vitamin $\mathrm{C}$ in tomatoes increased for in average two times between the green stage and red stage of maturity. Comparing the red and yellow tomato fruits used in our trials, we found that yellow tomatoes were richer in vitamin $\mathrm{C}$. At red stage of maturity yellow and red tomatoes had concentrations of $16.4 \pm 1.12 \mathrm{mg} \cdot 100$ $\mathrm{g}^{-1}$ and $12.6 \pm 1.26 \mathrm{mg} \cdot 100 \mathrm{~g}^{-1}$ vitamin $\mathrm{C}$, respectively. The obtained results agreed with George et al. 2011, who reported that concentration of vitamin $\mathrm{C}$ in fresh red and yel- 
low tomatoes was $15.8 \pm 1.1$ and $17.1 \pm 1.1 \mathrm{mg} \cdot 100 \mathrm{~g}^{-1}$, respectively.

One of the most well-known benefits of consuming tomato is its lycopene content, as researchers have found that tomatoes are an important source of dietary lycopene (Bhowmik et al., 2012). This compound appears to act as an antioxidant, neutralising free radicals that can damage cells in the human body. Lycopene has been demonstrated also to reduce oxidised-LDL cholesterol levels (Bhowmik et al., 2012; Abete et al., 2013).

The lycopene concentrations obtained in our study are in agreement with data reported by other authors (Choi et al., 2014; Del Giudice et al., 2015), but comparison is often difficult due to great influence of agronomic factors such as varieties and harvest time (Erba et al., 2013). In our study, the lycopene concentration in cherry type tomatoes was considerably higher than that in plum type tomatoes, regardless of the stage of maturity.

Our results showed that tomato variety SV0946TS contained the highest concentration of lycopene $(27.11 \pm 2.14$ $\mathrm{mg} \cdot 100 \mathrm{~g}^{-1}$ ), due to its dark colour. Lenucci et al. found that high-pigmented cultivars had a very high lycopene concentration, suggesting high variability in the tomato germplasm (Lenucci et al., 2006).

As expected, ripening was associated with a noticeable change in fruit pigmentation, and hence increase in lycopene concentration, by 10.4 or 12.2 fold in cherry and plum type tomatoes, respectively. Our results are in agreement with those previously reported (Choi et al., 2014; Del Giudice et al., 2015).

\section{CONCLUSIONS}

Tomato samples varied significantly according to the levels of the analysed compounds. In addition to fruit maturity, tomato variety exerted a significant effect on chemical composition of tomato. In summary, the concentration of total phenols, flavonoids, vitamin $\mathrm{C}$ and lycopene in cherry type tomatoes was considerably higher than in plum type tomatoes, regardless of the stage of maturity. Therefore, we can conclude that cherry type tomatoes are more "healthier" than plum or bigger size tomato fruits. Comparing red and yellow tomato fruits, yellow tomatoes were richer in vitamin C. During ripening, concentration of all analysed compounds increased depending on the type or variety of tomatoes: total phenol concentration by 1.7 times, total flavonoid concentration by 1.3 times, and vitamin $\mathrm{C}$ concentration by two times. The concentration of lycopene increased in average by 10.4 and 12.2 fold in cherry and plum type tomatoes, respectively.

\section{ACKNOWLEDGEMENTS}

This work was supported by the Latvian Council of Science, project No. 519/2012.

\section{REFERENCES}

Abete, I., Perez-Cornago, A., Navas-Carretero, S., Bondia-Pons, I., Zulet, M. A., Martinez, J. A. (2013). A regular lycopene enriched tomato sauce consumption influences antioxidant status of healthy young-subjects: A crossover study. J. Funct. Foods, 5, 28-35.

Bhowmik, D., Sampath Kumar, K. P., Paswan, S., Srivastava, S. (2012). Tomato - a natural medicine and its health benefits. J. Pharmacogn. Phytochem., 1 (1), 33-43.

Blum, A., Monir, M., Wirsansky, I., Ben-Arzi, S. (2005). The beneficial effects of tomatoes. Eur. J. Intern. Med., 16, 402-404.

Brandt, S., Pek, Z., Barna, E. (2006). Lycopene content and colour of ripening tomatoes as affected by environmental conditions. J. Sci. Food. Agric., 86, 568-572.

Burda, K. (2014). Potential role of carotenoids as antioksidants in human healihand disease. Nutrients, 6, 466-488.

Choi, S. H., Kim, D. S., Kozukue, N., Kim, H. J., Nishitani, Y., Mizuno, M., Levin, C. E., Friedman, M. (2014). Protein, free amino acid, phenolic, bcarotene, and lycopene content, and antioxidative and cancer cell inhibitory effects of 12 greenhouse-grown commercial cherry tomato varieties. $J$. Food Compos. Anal., 34, 115-127.

Choi, S. H., Lee, S. H., Kim, H. J., Lee, I. S., Kozukue, N., Levin, C. E., Friedman, M. (2010). Changes in free amino acid, phenolic, chlorophyll, carotenoid, and glycoalkaloid contents in tomatoes during 11 stages of growth and inhibition of cervical and lung human cancer cells by green tomato extracts. J. Agric. Food. Chem., 58, 7547-7556.

Das, S., Otani, H., Maulik, N., Das, D. K. (2005). Lycopene, tomatoes, and coronary heart disease. Free Radic. Res., 39, 449-455.

De Sousa, F. A., Neves, A. N., De Queiroz, M. E. L. R., Heleno, F. F., Teofilo, R., F., de Pinho, G. P. (2014). Influence of ripening stages of tomatoes in the analysis of pesticides by gas chromatography. J. Braz. Chem. Soc., 25 (8), 1431-1438.

Del Giudice, R., Raiola, A., Tenore, G.C., Frusciante, L., Baron, A., Monti, D.M., Rigano, M. M. (2015). Antioxidant bioactive compounds in tomato fruits at different ripening stages and their effects on normal and cancer cells. J. Funct. Foods, 18, 83-94.

Dumas, Y., Dadomo, M., Di Lucca, G., Grolier, P. (2003). Effects of environmental factors and agricultural techniques on antioxidant content of tomatoes. J. Sci. Food Agric., 83, 369-382.

Erba, D., Casiraghi, M.C., Ribas-Agustż, A., Ca'Ceres, R., Marfa,' O., Castellari, M. (2013). Nutritional value of tomatoes (Solanum lycopersicum L.) grown in greenhouse by different agronomic techniques. $J$. Food Compost. Anal., 31, 245-251.

García-Valverde, V., Navarro-Gonzalez, I., Garcia-Alsonso, J., Periago, M. J. (2013). Antioxidant bioactive compounds in selected industrial processing and fresh consumption tomato cultivars. Food Bioprocess Technol., 6, 391-402.

Gautier, H., Diakou-Verdin, V., Benard, C., Reich, M., Buret, M., Bourgaud, F., Poessel, J. L., Caris-Veyrat, C., Genard, M. (2008). How does tomato quality (sugar, acid, and nutritional quality) vary with ripening stage, temperature, and irradiance? J. Agric. Food Chem., 56, 1241-1250.

George, B, Tourniaire, F., Gautier, H., Goupy, P., Rock, E., Caris-Veyrat, C. (2011). Changes in the content of carotenoids, phenolic compounds and vitamin $C$ during technical processing and lyophilisation of red and yellow tomatoes. Food Chem. , 124, 1603-1611.

Helyes, L., Pék, Z. (2006). Tomato fruit quality and content depend on stage of maturity. HortScience, 41 (6), 1400-1401.

Kim, D., Jeong, S. W., Lee C. Y. (2003). Antioxidant capacity of phenolic phytochemicals from various cultivars of plums. Food Chem., 81, 321-326. 
Lenucci, M. S., Cadinu, D., Taurino, M., Piro, G., Dalessandro, G. (2006). Antioxidant composition in cherry and high-pigment tomato cultivars. $J$. Agric. Food Chem., 54, 2606-2613.

Maršic, N. K., Gašperlin, L., Abram, V., Budič, M., Vidrih, R. (2011). Quality parameters and total phenolic content in tomato fruits regarding cultivar and microclimatic conditions. Turk. J. Agric For,. 35, 185-194.

Nagata, M., Yamashita, I. (1992). Simple method for simultaneous determination of chlorophyll and carotenoids in tomato fruit. J. Japan Food Sci. Techn., 39, 925-928.

Palozza, P., Parrone, N., Catalano, A., Simone, R. (2010). Tomato lycopene and inflammatory cascade: Basic interactions and clinical implications. Curr. Med. Chem., 17, 2547-2563.

Pietta, P. G. (2000). Flavonoids as antioxidant. J. Nat. Prod., 63, 1035-1042.

Ried, K., Fakler, P. (2011). Protective effect of lycopene on serum cholesterol and blood pressure: Meta-analyses of interventional trials. Maturitas, 68, 299-310.

Sánchez-Rodríguez, E., Ruiz, J.M., Ferreres, F. , Moreno, D. A. (2012). Phenolic profiles of cherry tomatoes as influenced by hydric stress and rootstock technique. Food Chem., 134, 775-782.

Received 3 October 2016

Accepted in the final form 15 November 2017
Shi, J., Dai, Y., Kakuda, Y., Mittal, G., Xue, S.J. (2008). Effect of heating and exposure to light on the stability of lycopene in tomato purene. Food Control, 19, (5), 514-520.

Singleton, V. L., Orthofer, R., Lamuela-Raventos, R. M. (1999). Analysis of total phenols and other oxidation substrates and antioxidants by means of Folin-Ciocalteu reagent. Methods Enzymol., 299, 152-178.

Stewart, A. J., Bozzonet, S., Mullen, W., Jenkins, G. I., Lean, M. E. J., Croizer, A. (2000). Occurrence of flavonols in tomatoes and tomato-based products. J. Agric. Food Chem., 48, 2663-2669.

Vallverdś-Queralt, A., Medina-Remón, A., Andres-Lacueva, C., LamuelaRaventos, R. M. (2011). Changes in phenolic profile and antioxidant activity during production of diced tomatoes. Food Chem., 126, 1700-1707.

Vinha, A. F., Barreira, S. V. P., Costa, A. S. G., Alves, R. C., Oliveira, M. B. P. P. (2014a). Organic versus conventional tomatoes: Influence on phytsicochemical parameters, bioactive compounds and sensorial attributes. Food Chem. Toxicol., 67, 139-144.

Vinha, A. F., Alves, R. C., Barreira, S. V. P., Castro, A., Costa, A. S. G., Oliveira M. B. P. P. (2014b). Effect of peel and seed removal on the nutritional value and antioxidant activity of tomato (Lycopersicon esculentum L.) fruits. LWT Food Sci. Technol., 55, 197-202.

\section{BIOLOGISKI AKTĪVIE SAVIENOJUMI TOMĀTOS ATKARĪBĀ NO NOGATAVINĀŠANAS PAKĀPES}

Tomāti ir labi zināmi dārzeņi, kas, pateicoties to ķīmiskajam sastāvam, tajos esošajiem bioloğiski aktīvajiem savienojumiem, īpaši likopēnam, fenolu savienojumiem un C vitamīnam, raksturojas ar augstu uzturvērtību. Pētījuma mērkis bija izvērtēt bioloğiski aktīvo savienojumu izmaiņas atkarībā no tomātu šḳirnes un nogatavināšanas pakāpes. Desmit tomātu škirnes tika audzētas siltumnīcā un novāktas divās dažādās nogatavināšanas stadijās. Iegūtie rezultāti parādīja, ka analizētie rādītāji būtiski mainās atkarībā no tomātu škirnes un nogatavināšanas pakāpes. Vislielākais C vitamīna saturs tika konstatēts škirnes Sakura F1 tomātiem pilngatavībā, bet vismazākais — škiirnes Sunstreem F1 zaḷajiem tomātiem. Tomātu nogatavošanās laikā pieaug kopējo fenolu un flavonoīdu saturs. Visstraujākais pieaugums tika konstatēts škirnes Nugget F1 tomātos — fenolu saturs no $7,86 \mathrm{mg} \cdot 100 \mathrm{~g}^{-1}$ līdz $14,34 \mathrm{mg} \cdot 100 \mathrm{~g}^{-1}$ un flavonoīdu saturs no $6,09 \mathrm{mg} \cdot 100$ $\mathrm{g}^{-1}$ līdz $10,03 \mathrm{mg} \cdot 100 \mathrm{~g}^{-1}$. Likopēna saturs zaḷos tomātos ir l,oti mazs — vidēji $1 \mathrm{mg} \cdot 100 \mathrm{~g}^{-1}$. Visstraujākais tā pieaugums un vislielākais saturs tika konstatēts škirṇu SV0946TS $\left(27,11 \mathrm{mg} \cdot 100 \mathrm{~g}^{-1}\right)$ un Nectar F1 $\left(16,81 \mathrm{mg} \cdot 100 \mathrm{~g}^{-1}\right)$ sarkanajos tomātos. 